Research, part of a Special Feature on Traditional Ecological Knowledge and Adaptation to Global Environmental Change: North and South Perspectives

\title{
Traditional ecological knowledge among transhumant pastoralists in Mediterranean Spain
}

\author{
$\underline{\text { Elisa Oteros-Rozas }}^{1}, \underline{\text { Ricardo Ontillera-Sánchez }}^{1}, \underline{\text { Pau Sanosa }}^{1}$, Erik Gómez-Baggethun $^{1,2}{ }^{1}$ Victoria Reyes-García ${ }^{2,3}$
} and José A. González ${ }^{1}$

\begin{abstract}
Mobility is a millenary human strategy to deal with environmental change. An outstanding example of mobility is transhumance, an ancient pastoralist practice consisting of the seasonal migration of livestock between ecological regions following peaks in pasture productivity. The maintenance of transhumance depends partly on the preservation of related traditional ecological knowledge (TEK). We (a) identified and characterized social groups that hold transhumance-related TEK, (b) analyzed trends in transhumance-related TEK across generations and social groups, (c) examined the factors that influence variation in levels of TEK, and (d) analyzed elements of transhumance-related TEK as examples of adaptive strategies to cope with global change. We used transhumance on the Conquense Drove Road, a major active transhumant network in Spain, as a case study. Through an indepth literature review, participant observation, semistructured interviews, and a focus group discussion, we developed a survey to examine transhumance-related knowledge, practices, and beliefs. We collected survey data from 150 informants. Although a rich body of TEK persisted among transhumant shepherds, we found a marked loss of TEK among transhumants born after 1975, who scored one-fifth lower on survey items than other generations. The maintenance of transhumance on foot is the most important factor influencing TEK preservation. We conclude that in developed country settings, maintaining conditions for herd mobility can contribute to enhancing the adaptive capacity of agrarian societies to cope with global environmental change.
\end{abstract}

Key Words: adaptive strategy; drove road; environmental change; mobility; pastoralism; resilience

\section{INTRODUCTION}

Mobility has historically been a common social and ecological response to change and environmental risks (Agrawal 2008). Nomadic, seminomadic, and transhumant pastoralism constitute outstanding examples of mobility-based livelihood strategies. However, pastoralism is facing increasing challenges in the context of global change (e.g., FernándezGiménez and Le Febre 2006, Nori and Davies 2007, Dong et al. 2011).

Livelihoods based on the movement of livestock are adapted to areas where natural resource availability is highly variable through time and space (Dyson-Hudson and Dyson-Hudson 1980). Because periodic movement allows the adaptation of grazing pressure to the carrying capacity of pasturelands, mobile pastoralism has historically been the dominant type of livestock management strategy in semi-arid tropics, deserts, and highlands. Particularly in semi-arid countries, animal migratory systems are critical for making efficient use of the primary productivity of ecosystems across seasons (Alerstam et al. 2003, Manzano-Baena and Casas 2010).

Transhumance is a mobility strategy consisting of regular seasonal migration of livestock between summer and winter pastures, which allows adaptation to climate variability and matches grazing pressure with seasonal peaks in pasture availability (Ruiz and Ruiz 1986, Manzano-Baena and Casas
2010). Despite the acknowledged adaptive advantages of mobility, the practice of transhumance and other mobilitybased pastoralist strategies is declining worldwide (Dong et al. 2011). This decline is due to a variety of factors, including progressive integration into the global market economy, sedentarization policies, and institutional constraints that disfavor nomadic lifestyles (Davies and Hatfield 2007, Galvin 2009). These pressures, combined with drivers of global environmental change, such as climate and land use changes, challenge practitioners to sustain and protect mobile pastoralism worldwide in recognition of its social, cultural, economic, and ecological assets (Nori and Davies 2007).

In Mediterranean Europe, pastoralism has played a key role in shaping landscapes of High Nature Value, especially in mountainous ecosystems and rural areas (Hatfield and Davies 2006). Transhumance has been a major adaptive practice in Mediterranean pastoralist systems. The Mediterranean ecoregion is characterized by seasonality and highly unpredictable rainfall, which results in high climatic variability (Blondel 2006). Pasture productivity follows seasonal patterns and varies among years (Gómez Sal 2000). Transhumance persists in some countries like Spain, although with a different structure and at a smaller scale than in the past (Bunce et al. 2006, Manzano and Malo 2006, FernándezGiménez and Fillat Estaque 2012). 
Transhumance requires deep knowledge of the location and availability of natural resources, including spatial and temporal patterns, ecosystem types, responses to disturbances such as diseases, and formal and informal institutions that regulate transhumance. In this sense, traditional ecological knowledge (TEK), i.e., the cumulative body of knowledge, practices, and beliefs regarding the relationships of living things to their environment that evolves by adaptive processes and is handed down through generations (Berkes et al. 2000), becomes a crucial asset for mobile pastoralist livelihoods. In this study, we approach transhumance as a livestock management system and define transhumance-related TEK as the body of knowledge, practices, and beliefs associated with this pastoral practice. Our work assumes that TEK is an essential part of the social-ecological memory of transhumance because it contains ecological and cultural information that enables practitioners to adapt to change (Berkes et al. 2003, Fernández-Giménez and Fillat Estaque 2012). Furthermore, TEK can provide valuable information that complements scientific studies and improves the understanding and stewardship of ecosystems (Huntington 2000, Knapp and Fernández-Giménez 2009, FernándezGiménez and Fillat Estaque 2012).

We examine trends in and factors that influence TEK among transhumant pastoralists in Mediterranean Spain. Our research pursues four objectives: (1) identify and characterize social groups that hold transhumance-related TEK, (2) analyze trends in transhumance-related TEK across generations and social groups, (3) examine the factors that influence variation in levels of TEK, and (4) analyze elements of transhumancerelated TEK as examples of adaptive strategies.

\section{THE CASE STUDY}

We conducted this research as part of a larger study that was intended to evaluate ecosystem services related to transhumance on the Conquense Drove Road (CDR) (González et al. 2012), a major active transhumant network in Spain. The CDR is located in the northwestern Mediterranean Basin on the Iberian Peninsula (Fig. 1).

The Iberian Peninsula is dominated by a Mediterranean climate, which provides an ecological rationale for transhumance. The peninsula's geographic configuration is determined by a low-lying area in the south and west, which is the wintering area from which most drove roads depart to northern mountainous areas. Winter pastures are situated in areas where the mean temperature during the coldest month is above $6^{\circ} \mathrm{C}$, whereas summer pastures lie in areas where the mean temperature in the hottest month does not exceed $17^{\circ} \mathrm{C}$ (Garzón 2001).

In Spain, transhumance peaked at the end of the 18th century, when an estimated 4 million sheep were moved distances up to $700 \mathrm{~km}$ twice yearly along an extensive network of drove roads (Bilbao and Fernández de Pinedo 1982). According to
Cazorla et al. (2008), this network extended more than 125,000 $\mathrm{km}$ and occupied ca. $422,000 \mathrm{ha}$, or $0.83 \%$ of the country. The network comprises different types of droves: royal drove roads, termed "cañadas reales," with legal widths of ca. $75 \mathrm{~m}$, and smaller trails, known as "cordeles" and "veredas," with widths of 37 and $20 \mathrm{~m}$, respectively. With the breakdown of the Spanish monopoly on Merino wool in the 19th century, pastoralism and transhumance in Spain progressively declined (García-Martín 2004). After 1943, the use of rail transport gradually led to the abandonment of the routes on foot (Abellán and Olivera 1979, Bacaicoa Salaverri et al. 1993). For about 50 years from the early 1940 s to the early 1990s, trains were the most common means of sheep transportation because they were more comfortable than walking and were inexpensive. However, shepherds continued to move their herds on foot for up to five days from their rangelands to train stations, which partially maintained the foot-based tradition.

Fig. 1. Map of the Conquense Drove Road social-ecological network showing summering and wintering areas (A) and the annual cycle of transhumant movements on foot (B).

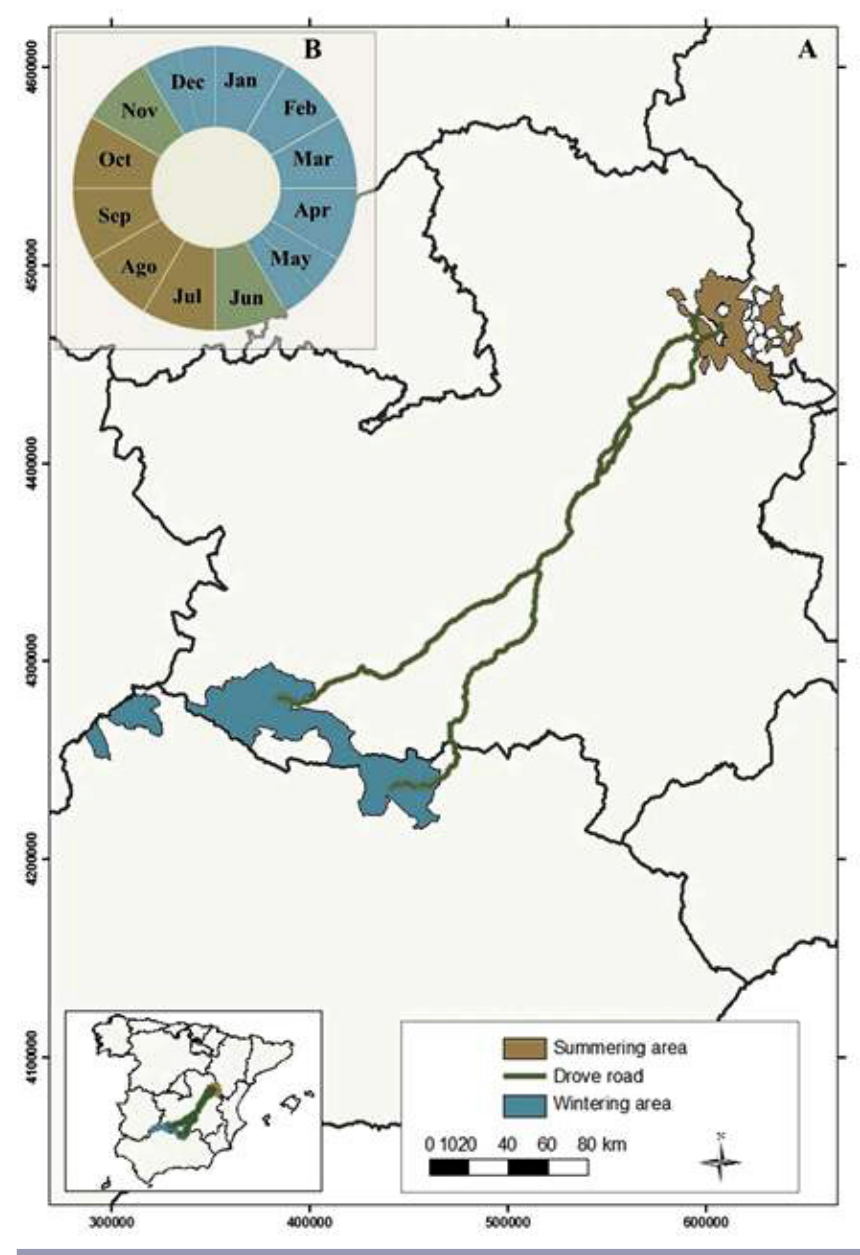


The development of the Spanish highway network in the 1980s and economic growth following Spain's integration into the European Union (EU) made truck transportation of herds an affordable and more comfortable alternative for shepherds. Shepherds faced declining competition and increasing production costs as a result of intensification and sedentarization, and EU subsidies accounted for increasing proportions of their incomes (García-Martínez et al. 2009). During the 1980s, most shepherds in Spain abandoned transhumance on foot in favor of railway and truck transport (Ruiz and Ruiz 1986, Manzano-Baena and Casas 2010). This tendency peaked in the early 1990s, when the state railway company eliminated livestock trains (Bacaicoa Salaverri et al. 1993). At that time, some shepherds resumed transhumance on foot on the CDR for primarily economic and cultural identity reasons: truck transportation costs consumed approximately $10 \%$ of revenues, and each trip on foot recalled, revived, and reinforced the transhumant identity. In 2006, after the appearance of bluetongue disease, preventive sanitary restrictions that were applied throughout Europe limited livestock movement, which reduced the total number of livestock head and transhumant shepherds in Spain.

Recent increases in the production costs of products such as fodder and oil have encouraged some shepherds to resume transhumance on foot (Fernández-Giménez and Fillat Estaque 2012, Oteros-Rozas et al. 2012b). This shift has been possible in part because of the maintenance of the extensive network of drove roads that connect winter and summer pasturelands. The 1995 Drove Road Act granted legal protection to this public network in recognition of the benefits drove roads provide by facilitating extensive grazing and the maintenance of local breeds and ecological corridors (García-Martín 2004, Gómez Sal and Lorente 2004, Mangas-Navas 2004). Several authors have suggested that transhumance remains relevant in developed country settings and has provided important insights on how to adapt to changing economic and social conditions (Fernández-Giménez and Fillat Estaque 2012). However, the same authors have also noted that an ongoing aging process due to limited intergenerational turnover threatens much of the TEK associated with pastoralist systems. Social and market forces seem to be driving the loss of customary herders' knowledge in other TEK systems in rural Spain (e.g., Ruiz and Ruiz 1986, Gómez-Baggethun et al. 2010, 2012, Reyes-García et al. 2010).

The CDR has been characterized as a social-ecological network (sensu Janssen et al. 2006), i.e., an "adaptive network of biophysical and social flows generated and maintained by the movement of shepherds and livestock" (Oteros-Rozas et al. 2012a, p. 243). It comprises three areas: (a) a summering area, (b) a wintering area, and (c) the drove road (Fig. 1). The summering area, where herds stay from July to October, is located in the eastern Montes Universales in Teruel, Guadalajara, and Cuenca provinces. This area is characterized by semideciduous vegetation, coniferous forests, and agricultural patches where fodder crops are grown. The wintering area, where herds stay from December to May, is located in the southeastern Sierra Morena and the southern fields of La-Mancha. This area is characterized by a typical Mediterranean dehesa landscape, an agrosilvopastoral ecosystem aimed mainly at extensive livestock grazing. The drove road is a $75 \mathrm{~m}$ wide and approximately $410 \mathrm{~km}$ long corridor that crosses predominantly cultivated areas in the Iberian Central Plateau which consist mostly of vineyards, olive orchards, and fields of sunflowers and cereals. In 2009, local agrarian offices granted livestock movement permits through the CDR to 87 transhumant shepherds, most of whom used trucks but 15 of whom walked the drove with approximately 8900 sheep and 1200 cows (Oteros-Rozas et al. 2012b).

\section{METHODS}

\section{Data collection}

A team of researchers who had worked with local transhumants for about 3 years conducted fieldwork from June 2010 to August 2011. Participant observation during nineteen 1-5-week periods was a major source of information. Data collection was organized in three phases: (1) background information collection, (2) focus group, and (3) systematic data collection (Fig. 2).

\section{Background information}

The collection of background information began with an indepth review of documents and archives in two local museums, the Museo de la Trashumancia in Guadalaviar and the Museo de Ganadería Extensiva in Checa, and the Centro de Estudios de la Trashumancia. Interviews with shepherds were also retrieved from the audio archives of the Museo de la Trashumancia and were partially transcribed and processed using qualitative data analysis software.

Between June and September 2010, we conducted semistructured interviews with 11 key informants, two women and nine men aged 45-93 years. All key informants were transhumant or ex-transhumant shepherds, including retired and/or settled individuals. We drew on the knowledge of informants living in summering areas and used a snowball sampling technique (Bernard 2005) to select shepherds with long family and personal traditions as transhumants. We based the number of key informants on the recurrence of similar information in interviews. The sample size for semistructured interviews represented 5-10\% of the survey sample. Interviews were structured around six topics: (1) weather forecasts and indicators of water and pasture availability; (2) knowledge and practices related to livestock management, such as animal behavior, herd composition, wool production, sanitary practices, use of farming tools, and assistance of dogs and horses; (3) management of pasturelands and croplands, 
Fig. 2. Methods of data collection and analysis (TEK: traditional ecological knowledge).

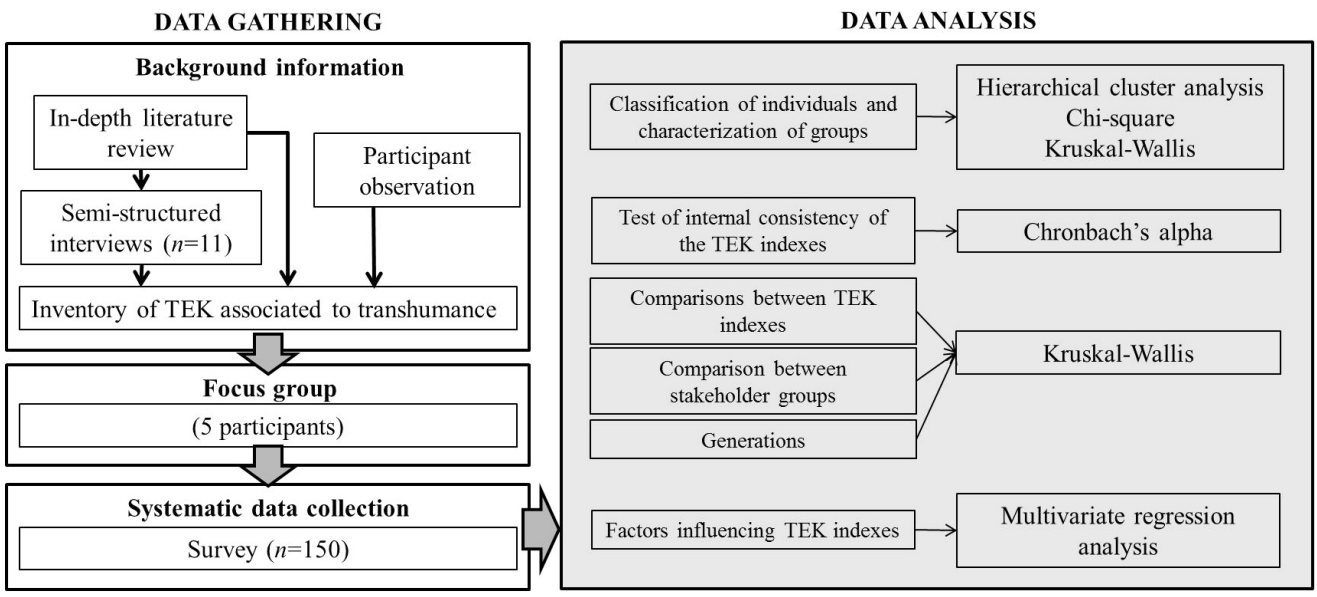

including plant species and their distribution and properties for livestock grazing; (4) formal and informal institutions, such as land tenure regimes, farmers' associations, social hierarchies, and division of tasks among shepherds; (5) changes in resources, technologies, practices, schedules, knowledge, and household livelihood strategies; and (6) other information related to the cultural transmission of transhumance-related TEK, such as songs, poems, legends, proverbs, and recipes. The interviews were recorded and then transcribed and tagged using qualitative data analysis software. Based on the literature review and analysis of interviews, we built an inventory of transhumance-related TEK. We identified about 90 practices and beliefs and classified them in the six topical categories used to structure the interviews.

\section{Focus group}

We organized a focus group to discern well-established transhumance-related TEK from local variants. Five of the 11 key informants from the first phase, two women and three men, participated in this focus group.

From the preliminary inventory of transhumance-related TEK, we selected items for a focus group discussion based on four criteria: (1) relevance to the transhumance system, (2) practices that had changed substantially in the last 50 years, (3) practices related to adaptation to disturbances, and (4) importance for the management of natural resources, such as pastures, croplands, and forests. We selected only items mentioned by at least two informants during indepth interviews.

\section{Systematic data collection}

We applied a methodology similar to that of GómezBaggethun et al. (2010), and used the background information and focus group discussion to construct a transhumance- related TEK questionnaire. The questionnaire consisted of 36 open-ended questions about transhumance-related practices, knowledge, and beliefs (Appendix), and solicited information about interviewees' sociocultural and demographic characteristics (Table 1).

The survey was administered face-to-face to 150 people. To locate informants, we used the last available census of transhumants in the area, which included individuals working on 95 livestock farms who had conducted transhumance between 2004 and 2009 (Oteros-Rozas et al. 2012b). More than $95 \%$ of farms in this census were surveyed. We interviewed the head of each livestock farm and, when possible, one or two of his sons/daughters. The survey was carried out during the summer vacation period to ensure the inclusion of relatives who had migrated to urban areas. We focused mainly on men because the local gender-based division of labor typically assigns livestock-raising practices to men. Three outliers that did not fit within the 95\% confidence interval for TEK scores were excluded from the analyses, which resulted in a final sample of 147 interviewees.

\section{Data analysis}

Using responses to survey questions, we constructed an index that served as a proxy for individual transhumance-related TEK (Reyes-García et al. 2007, Gómez-Baggethun et al. 2010). To evaluate informants' responses to survey questions, we constructed an answer key using data obtained in the background information phase, the focus group discussion, and the experience of the team that carried out fieldwork. Each response was coded on a scale ranging from 0 , indicating a completely incorrect response or no knowledge, to 1 , indicating a completely correct response, depending on the degree to which the informant's answer matched the answer key. 
Table 1. Description and descriptive statistics of variables used in the analyses.

\begin{tabular}{|c|c|c|c|}
\hline Variables & Description & Mean & $\mathrm{SD}$ \\
\hline \multicolumn{4}{|l|}{ Dependent variables } \\
\hline TEK_general & Sum of the score obtained in 36 questions related to transhumance. Standardized 0-100 (continuous) & 59.76 & 12.78 \\
\hline TEK_past & $\begin{array}{l}\text { Sum of the score obtained in } 14 \text { questions referring to how things were done in the past, ancient } \\
\text { practices, or situations that do not occur nowadays. Standardized } 0-100 \text { (continuous) }\end{array}$ & 51.28 & 14.00 \\
\hline TEK_transhumance & $\begin{array}{l}\text { Sum of the score obtained in } 14 \text { questions referring exclusively to the transhumance livestock raising } \\
\text { model. Standardized } 0-100 \text { (continuous) }\end{array}$ & 57.04 & 16.40 \\
\hline TEK_environment & $\begin{array}{l}\text { Sum of the score obtained in } 11 \text { questions referring to the relationships to and management of } \\
\text { ecosystems. Standardized } 0-100 \text { (continuous) }\end{array}$ & 53.94 & 15.07 \\
\hline TEK_indicators & $\begin{array}{l}\text { Sum of the score obtained in three questions referring to indicators of meteorological changes. } \\
\text { Standardized } 0-100 \text { (continuous) }\end{array}$ & 70.80 & 20.59 \\
\hline TEK_sanitary & $\begin{array}{l}\text { Sum of the score obtained in four questions referring to sanitary practices for maintaining or restoring } \\
\text { animal health. Standardized } 0-100 \text { (continuous) }\end{array}$ & 32.40 & 12.74 \\
\hline $\begin{array}{l}\text { Su } \\
\text { pe } \\
\text { in } \\
\text { St }\end{array}$ & $\begin{array}{l}\text { Sum of the score obtained in seven questions referring to the use of practices ( } 3 \text {, indicating that the } \\
\text { person used the practice in } 2011 ; 2 \text {, indicating use of the practice at least once in the last } 5 \text { years; } 1 \text {, } \\
\text { indicating use more than } 5 \text { years ago; and } 0 \text {, indicating that the person had never used the practice). } \\
\text { Standardized } 0-100 \text { (continuous) }\end{array}$ & 1.10 & 0.59 \\
\hline \multicolumn{4}{|c|}{ Independent variables (continuous) } \\
\hline Age & Age of the informant, in years & 53.29 & 18.16 \\
\hline $\begin{array}{l}\text { Years transhumance on } \\
\text { foot }\end{array}$ & Number of years the informant had done the transhumance on foot & 3.62 & 5.71 \\
\hline $\begin{array}{l}\text { Years transhumance by } \\
\text { truck }\end{array}$ & Number of years the informant had done the transhumance by truck & 10.16 & 7.16 \\
\hline $\begin{array}{l}\text { Years transhumance by } \\
\text { train }\end{array}$ & Number of years the informant had done the transhumance by train & 10.47 & 9.86 \\
\hline \multicolumn{3}{|c|}{ Independent variables (dummies and ordinals) } & $\%$ \\
\hline Male & Gender of the respondent $($ male $=1$, female $=0)$ & & 89.12 \\
\hline $\begin{array}{l}\text { Children of } \\
\text { transhumant }\end{array}$ & Is the informant the son/daughter of a transhumant? 1: yes, 0 : no & & 80.27 \\
\hline $\begin{array}{l}\text { Livestock raising as } \\
\text { main occupation }\end{array}$ & Is the informant currently a full-time livestock raiser? 1 : yes, $0:$ no & & 78.91 \\
\hline $\begin{array}{l}\text { Transhumant on foot at } \\
\text { least once }\end{array}$ & Has the informant ever done transhumance on foot? 1: yes, 0: no & & 51.02 \\
\hline $\begin{array}{l}\text { Transhumant by train at } \\
\text { least once }\end{array}$ & Has the informant ever done transhumance by truck? 1: yes, 0: no & & 68.02 \\
\hline Transhumant on foot & Does the informant currently practice transhumance on foot? 1: yes, 0 : no & & 11.56 \\
\hline Transhumant by truck & Does the informant currently practice transhumance by truck? 1: yes, $0:$ no & & 33.33 \\
\hline Transhumant & Does the informant currently practice transhumance? 1 : yes, 0 : no & & 42.86 \\
\hline Generation & Ordinal & & \\
\hline Born after 1975 & young & & 24.49 \\
\hline Born: 1960-1974 & middle & & 23.81 \\
\hline Born: $1945-1959$ & mature & & 21.77 \\
\hline Born before 1945 & elder & & 29.93 \\
\hline Education level & Ordinal & & \\
\hline No studies & 0 & & 8.16 \\
\hline Studied until age of 10 & 1 & & 14.29 \\
\hline Primary education & 2 & & 46.26 \\
\hline Secondary education & 3 & & 17.01 \\
\hline High school & 4 & & 2.72 \\
\hline Vocational education & 5 & & 8.16 \\
\hline University & 6 & & 3.40 \\
\hline Last transhumance & Ordinal & & \\
\hline Never & 0 & & 6.12 \\
\hline Before 1975 & 1 & & 5.44 \\
\hline $1975-1993$ & 2 & & 10.88 \\
\hline 1994-2005 & 3 & & 23.81 \\
\hline After 2006 & 4 & & 53.74 \\
\hline
\end{tabular}


We also examined different components of TEK using five subindexes constructed with the partial sums of questions that referred to specific bodies of TEK (Table 1, Appendix): (1) "TEK_past," which included 14 questions about ancient and past practices or situations that do not currently occur, such as wolf attacks; (2) "TEK_transhumance," which included 14 questions that referred exclusively to the transhumance livestock raising system; (3) "TEK_environment," which included 11 questions regarding relationships to ecosystem management; (4) "TEK_indicators," which included three questions about indicators of meteorological change; and (5) "TEK_sanitary," which included four questions about traditional sanitary practices for maintaining or restoring animal health.

Because practice is a major component of TEK systems (Berkes et al. 2000), we explored relationships between the actual use of some current practices and TEK preservation (Reyes-García et al. 2007) by asking "When was the last time you used this practice?" for a subset of seven questions. We then assigned scores of use as follows: 3 , indicating that the person used the practice in $2011 ; 2$, indicating use of the practice at least once in the last 5 years; 1 , indicating use more than 5 years ago; and 0 , indicating that the person had never used the practice. We calculated another index named "Use" as the average of partial scores obtained for these seven questions. To facilitate comparability, we transformed all TEK and Use scores to percentages. Cronbach's alpha tests were used to check the internal consistency of all TEK indexes (Appendix) (see also Reyes-García et al. 2006, GómezBaggethun et al. 2010).

To characterize the sample population, we performed a hierarchical cluster analysis (HCA) that classified interviewees according to TEK scores. We used the Bray Curtis distance and Ward (1963) methods as agglomerative techniques. Then, we used Kruskal-Wallis and Chi-square tests to characterize groups defined by HCA according to sociocultural and demographic variables (García-Llorente et al. 2011).

We used informants' reported ages to create the "generation" variable, which contained four age classes: young, born after 1975; middle-aged, born between 1960 and 1974; mature, born between 1945 and 1959; and elderly, born before 1945. We also created a "last transhumance" variable to explore the interference of potential breaking points in the continuity of transhumance: Spanish rural exodus, for which we considered 1975 to be a critical point; withdrawal of public trains to carry livestock in 1993; and the bluetongue disease outbreak in 2006. The following values were used for this variable: 0 , the informant had never practiced transhumance; 1, last transhumance before 1975; 2, last transhumance between 1975 and 1993; 3, last transhumance between 1994 and 2005; and 4, abandonment of transhumance after 2006.
We used Kruskal-Wallis and post hoc Tukey's tests to compare the distributions of TEK and Use indexes. Differences in indexes among interviewees were also explored with Kruskal-Wallis and Chi-square tests. To explore the factors influencing TEK, we performed ordinary least-squares regressions using TEK_general, TEK_past, TEK_transhumance, and TEK_environment scores as dependent variables and sociocultural and demographic characteristics as explanatory variables. All quantitative variables were $\ln$-transformed prior to analyses. We used adjusted $R^{2}$ and the Akaike information criterion to compare the models' predictive power and parsimony, respectively. We forced the inclusion of education level in all models to reveal its positive/negative influence.

\section{RESULTS}

\section{Characterization of traditional ecological knowledge holders}

The survey sample comprised 17 women and 133 men aged $20-94($ mean $=53)$ years. About $80 \%$ of interviewees were the children of transhumants, and approximately the same proportion were active full-time livestock raisers. Half of the survey sample had conducted transhumance on foot at least once in their lifetime, and $68 \%$ had traveled by train with livestock at least once. Only $12 \%$ and $33 \%$ of informants had conducted transhumance on foot and by truck, respectively, in 2011 (Table 1).

Based on interviewees' answers to the 36 TEK questions, the HCA divided the sample into four groups (Table 2):

- Group A included the youngest people in the sample (age $<46$ years), who were not currently transhumants or livestock raisers but who had accompanied other transhumants on foot for about 3 years.

- Group B included middle-aged and young people (2361 years), of which $64 \%$ raised livestock, with no tradition of transhumance in their grandparents' generation. This group also included young people who had accompanied older shepherds, including friends and family members, on a few transhumance trips on foot.

- Group C included mostly middle-aged informants (2279 years), although they were older than interviewees in group B. This group included individuals who practiced transhumance by truck, and $87 \%$ of the group comprised ex-transhumants who continued to raise livestock but had discontinued the practice of transhumance, mainly after 2006.

- Group D included elderly individuals (mean age $=63$ years), most of whom were experienced retired or current transhumants, and heirs of transhumants. This group included $65 \%$ of currently active transhumants on foot. 
Table 2. Characterization of interviewee groups resulting from hierarchical cluster analysis.

\begin{tabular}{|c|c|c|c|c|c|c|}
\hline Variables & $\chi^{2}$ & $p$ value & Group A & Group B & Group C & Group D \\
\hline Age (years; mean \pm SD) & 44.983 & $<0.0001$ & $31 \pm 7$ & $42 \pm 16$ & $49 \pm 16$ & $63 \pm 15$ \\
\hline Years transhumance on foot (average) & 29.667 & $<0.0001$ & 3 & 1 & 2 & 6 \\
\hline Years transhumance by truck (average) & 1.937 & 0.58 & 8 & 10 & 10 & 11 \\
\hline Years transhumance by train (average) & 28.361 & $<0.0001$ & 3 & 6 & 9 & 15 \\
\hline Male $(n)$ & 1.308 & 0.727 & 7 & 24 & 42 & 57 \\
\hline Children of transhumant $(\%)$ & 3.433 & 0.318 & 75 & 64 & 71 & 73 \\
\hline Full-time livestock raiser (\%) & 2.558 & 0.465 & 13 & 64 & 87 & 86 \\
\hline Transhumant on foot at least once (\%) & 3.199 & 0.362 & 25 & 11 & 44 & 74 \\
\hline Transhumant by train at least once $(\%)$ & 1.359 & 0.715 & 13 & 36 & 69 & 86 \\
\hline Transhumant on foot $(\%)$ & 4.377 & 0.224 & 0 & 7 & 9 & 17 \\
\hline Transhumant by truck $(\%)$ & 12.534 & 0.006 & 0 & 50 & 42 & 24 \\
\hline Transhumant $(\%)$ & 8.923 & 0.030 & 0 & 57 & 47 & 41 \\
\hline Grandchildren of a transhumant on foot $(\%)$ & 8.360 & 0.039 & 3 & 15 & 14 & 25 \\
\hline Generation (mode) & 51.812 & $<0.0001$ & 1 & 1 & 3 & 4 \\
\hline Education level (mode) & 14.986 & 0.663 & 3 & 2 & 2 & 2 \\
\hline Last transhumance (mode) & 12.908 & 0.376 & 4 & 4 & 4 & 4 \\
\hline$N$ & & & 8 & 28 & 45 & 66 \\
\hline
\end{tabular}

\section{Trends in cultural transmission and use of traditional ecological knowledge}

Among the six TEK indexes, TEK_indicators was highest and TEK_sanitary was lowest; both were statistically significant different from the other indexes (Fig. 3). Among the remaining four indexes, TEK_past and TEK_environment were significantly lower than the other two indexes. The Use index was lower than most TEK indexes. Only four of six TEK indexes yielded Cronbach's alpha values > 0.6 (Appendix), indicating high internal consistency. Thus, we considered only the following four indexes in further analyses: TEK_general, TEK_past, TEK_transhumance, and TEK_environment.

Fig. 3. Comparison of box-plot distributions for traditional ecological knowledge (TEK) and Use indexes. Different letters denote significant differences among groups (post hoc non-parametric Tukey's test, $p<0.05$ ).

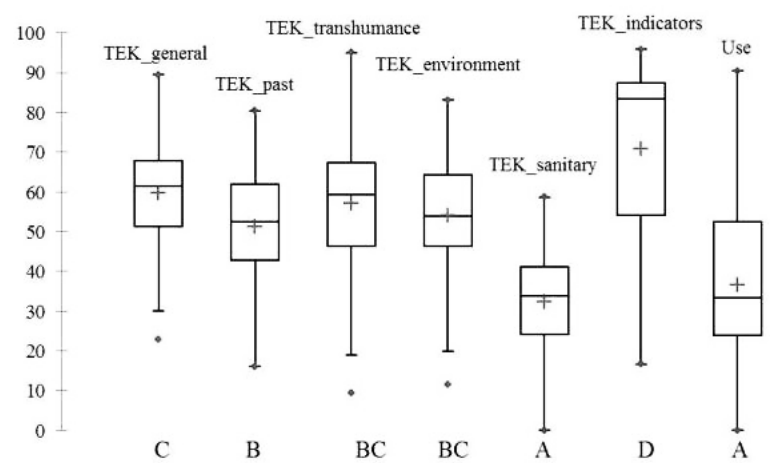

Mean TEK scores for these four indexes differed significantly among groups of interviewees (Table 3). The eldest and most experienced transhumants, categorized in group D, scored significantly higher than did those in the other three groups. Scores were lowest in group A. We also found significant differences in TEK indexes among those who had predominantly abandoned the activity, classified in groups A and $\mathrm{B}$, and the rest of the sample. TEK scores were significantly lower in the young generation than in the rest of the sample; this difference was $20.2 \%$ on average for TEK_general and $25.3 \%$ for TEK_past.

The Use index also differed significantly among groups of interviewees and generations. We observed a significant disparity between group $\mathrm{A}$, which contained young individuals who had lost the link with transhumance and scored lowest, and the rest of the sample. We found no difference in the Use index among groups $\mathrm{B}, \mathrm{C}$, and $\mathrm{D}$. An intergenerational break in the use of TEK was apparent between the middle-aged and mature generations, with the latter achieving the highest scores. The Use index was lowest among elders because most of these individuals were retired.

Trends in the TEK_general and Use indexes across generations showed dissimilar patterns (Fig. 4). TEK scores were similar in the middle-aged and mature generations, but the Use index was highest among interviewees aged 51-68 years. We also found that patterns of the TEK_general and Use indexes differed among groups. The Use index was similar between groups $\mathrm{B}$ and $\mathrm{C}$, but TEK scores were higher in group $\mathrm{C}$, which comprised truck-based transhumants and settled extranshumants, than in group B. 
Table 3. Comparison of mean traditional ecological knowledge (TEK) and Use indexes among interviewee groups defined by hierarchical cluster analysis (HCA) and generations.

\begin{tabular}{|c|c|c|c|c|c|c|c|c|c|c|c|}
\hline \multirow[t]{2}{*}{ Variables } & \multirow[t]{2}{*}{ Values } & \multicolumn{2}{|c|}{ TEK_general } & \multicolumn{2}{|c|}{ TEK_past } & \multicolumn{2}{|c|}{ TEK_transhumance } & \multicolumn{2}{|c|}{ TEK_environment } & \multicolumn{2}{|r|}{ Use } \\
\hline & & Mean TEK & $\begin{array}{c}\text { Kruskal- } \\
\text { Wallis }\end{array}$ & Mean TEK & $\begin{array}{c}\text { Kruskal- } \\
\text { Wallis }\end{array}$ & Mean TEK & $\begin{array}{c}\text { Kruskal- } \\
\text { Wallis }\end{array}$ & Mean TEK & $\begin{array}{c}\text { Kruskal- } \\
\text { Wallis }\end{array}$ & Mean Use & Kruskal-Wallis \\
\hline \multirow[t]{2}{*}{$\begin{array}{l}\text { Groups } \\
\text { HCA }\end{array}$} & A & $29.91^{\mathrm{A}}$ & $\chi_{8}^{2}=103.39$ & $19.84^{\mathrm{A}}$ & $\chi^{2}=84.01^{\S}$ & $24.23^{\mathrm{A}}$ & $\chi^{2}=88.70^{8}$ & $22.59^{\mathrm{A}}$ & $\chi^{2}=61.02^{\S}$ & $10.12^{\mathrm{A}}$ & $\chi^{2}=15.66^{8}$ \\
\hline & $\begin{array}{l}\text { B } \\
\text { C } \\
\text { D }\end{array}$ & $\begin{array}{l}47.58^{\mathrm{A}} \\
58.06^{\mathrm{B}} \\
69.71^{\mathrm{C}}\end{array}$ & & $\begin{array}{l}40.11^{\mathrm{AB}} \\
48.73^{\mathrm{B}} \\
61.56^{\mathrm{C}}\end{array}$ & & $\begin{array}{l}39.98^{\mathrm{A}} \\
56.41^{\mathrm{B}} \\
68.69^{\mathrm{C}}\end{array}$ & & $\begin{array}{l}43.39^{\mathrm{A}} \\
52.79^{\mathrm{B}} \\
63.00^{\mathrm{C}}\end{array}$ & & $\begin{array}{l}36.91^{\mathrm{B}} \\
37.04^{\mathrm{B}} \\
39.47^{\mathrm{B}}\end{array}$ & \\
\hline Generations & $\begin{array}{l}\text { young } \\
\text { middle } \\
\text { mature } \\
\text { elder }\end{array}$ & $\begin{array}{l}49.98^{\mathrm{A}} \\
60.65^{\mathrm{B}} \\
60.97^{\mathrm{B}} \\
66.17^{\mathrm{B}}\end{array}$ & $\chi^{2}=29.49^{\S}$ & $\begin{array}{l}40.52^{\mathrm{A}} \\
50.03^{\mathrm{AB}} \\
52.86^{\mathrm{BC}} \\
59.92^{\mathrm{C}}\end{array}$ & $\chi^{2}=36.76^{8}$ & $\begin{array}{l}45.98^{\mathrm{A}} \\
58.75^{\mathrm{B}} \\
59.27^{\mathrm{B}} \\
63.11^{\mathrm{B}}\end{array}$ & $\chi^{2}=19.84^{8}$ & $\begin{array}{l}44.00^{\mathrm{A}} \\
55.76^{\mathrm{B}} \\
55.29^{\mathrm{B}} \\
59.65^{\mathrm{B}}\end{array}$ & $\chi^{2}=18.87^{\S}$ & $\begin{array}{l}33.47^{\mathrm{A}} \\
38.23^{\mathrm{AB}} \\
46.73^{\mathrm{B}} \\
30.63^{\mathrm{A}}\end{array}$ & $\chi^{2}=14.13^{\S}$ \\
\hline Mean & & 59.760 & & 51.278 & & 57.044 & & 53.942 & & 36.640 & \\
\hline \multicolumn{12}{|c|}{$\begin{array}{l}\dagger \text { significant at the } \leq 10 \% \text { level } \\
\text { significant at the } \leq 5 \% \text { level } \\
\text { significant at the } \leq 1 \% \text { level }\end{array}$} \\
\hline
\end{tabular}

Fig. 4. Comparison of traditional ecological knowledge (TEK_general) and Use indexes (mean $\ddagger$ standard deviation) among generations and groups defined by hierarchical cluster analysis (HCA).

$\left.\begin{array}{r}100 \\ 90 \\ 80 \\ 70 \\ 60 \\ 50 \\ 40 \\ 30 \\ 20 \\ 10 \\ 0\end{array}\right]-$

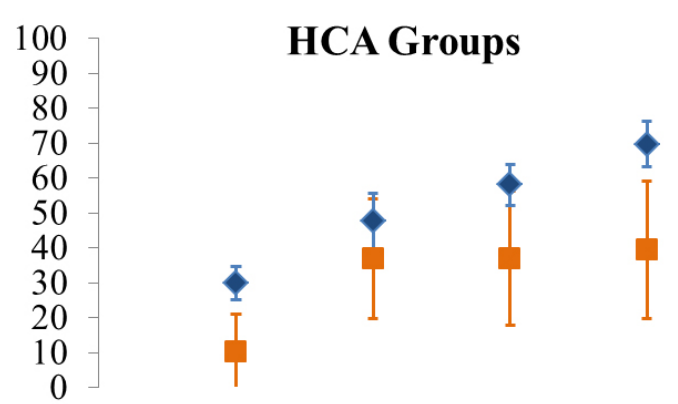

Group A Group B Group C Group D

$\diamond$ TEK_general
$\square$ Use

\section{Factors explaining levels of traditional ecological knowledge}

Several sociodemographic variables were associated with our measure of TEK_general (Table 4). Transhumance practice on foot and male gender were most positively and significantly associated with TEK. TEK_general scores were significantly lower among young informants than among middle-aged and mature informants, whereas scores were highest among elders. Other characteristics, such as raising livestock and train-based transhumance experience, were also positively associated with higher TEK scores, although the coefficients were small.

We found significant associations between most sociodemographic variables and TEK_past, except that current transhumance practice and train-based transhumance experience were not components of the best model. Instead, shepherds who had recently practiced transhumance tended to score slightly higher than those who had abandoned the practice earlier. Male gender and full-time livestock raising were the aspects of general transhumance-related TEK that were most closely related to past practices.

The best model for TEK_transhumance contained most variables included in the TEK_general model, except for livestock raising as a main occupation, which was not significantly related, and train-based transhumance experience, which was included in the best model but was not significant. For this index, current transhumants on foot and men showed the strongest relationships with higher TEK scores.

Finally, variables associated with TEK_environment showed the same patterns and significance as in the regression model for TEK_general, with one exception. Experience with trainbased transhumance at least once in the informant's lifetime was not significant in the best model for this index. 
Table 4. Results of multiple regression analyses performed to identify factors influencing traditional ecological knowledge (TEK) indexes.

\begin{tabular}{|c|c|c|c|c|c|c|c|c|}
\hline \multirow[t]{3}{*}{ Explanatory Variables } & \multicolumn{8}{|c|}{ Dependent Variables } \\
\hline & \multicolumn{2}{|c|}{ TEK_general } & \multirow{2}{*}{\multicolumn{2}{|c|}{$\begin{array}{c}\text { TEK_past } \\
\text { Coefficient } t \text { value }\end{array}$}} & \multicolumn{2}{|c|}{ TEK_transhumance } & \multirow{2}{*}{\multicolumn{2}{|c|}{$\begin{array}{l}\text { TEK_environment } \\
\text { Coefficient } t \text { value }\end{array}$}} \\
\hline & Coefficient $t$ & value & & & Coefficient & value & & \\
\hline Last transhumance & $\wedge$ & $\wedge$ & -0.093 & -1.179 & $\wedge$ & $\wedge$ & $\wedge$ & $\wedge$ \\
\hline Years he/she has done transhumance on foot & $\wedge$ & $\wedge$ & $\wedge$ & $\wedge$ & $\wedge$ & $\wedge$ & $\wedge$ & $\wedge$ \\
\hline Years he/she has done transhumance by truck & $\wedge$ & $\wedge$ & $\wedge$ & $\wedge$ & $\wedge$ & $\wedge$ & $\wedge$ & $\wedge$ \\
\hline $\begin{array}{l}\text { Years he/she has done transhumance by train } \\
\text { Generation }\end{array}$ & 0.085 & 1.097 & 0.189 & $2.361 \ddagger$ & 0.173 & $2.013+$ & 0.077 & 0.844 \\
\hline Young & -0.193 & $-2.905 \S$ & -0.184 & $-2.299 \S$ & -0.179 & -2.381 末 & -0.211 & $-2.691 \S$ \\
\hline Middle & $\wedge$ & $\wedge$ & $\wedge$ & $\wedge$ & $\wedge$ & $\wedge$ & $\wedge$ & $\wedge$ \\
\hline Mature & $\wedge$ & $\wedge$ & $\wedge$ & $\wedge$ & $\wedge$ & $\wedge$ & $\wedge$ & $\wedge$ \\
\hline Elder & 0.185 & $3.050 \S$ & 0.169 & $2.124 \ddagger$ & 0.134 & $1.957 \dagger$ & 0.129 & $1.800 \dagger$ \\
\hline Male & 0.295 & $4.776 \S$ & 0.220 & $3.251 \S$ & 0.269 & $3.916 \S$ & 0.208 & $2.850 \S$ \\
\hline Formal education above primary studies & -0.084 & -1.254 & -0.037 & -0.455 & -0.099 & -1.342 & -0.078 & -0.993 \\
\hline Livestock raising as main occupation & 0.202 & $3.370 \S$ & 0.264 & $3.455 \S$ & $\wedge$ & $\wedge$ & 0.162 & $2.285 \ddagger$ \\
\hline $\mathrm{He} / \mathrm{she}$ is currently a transhumant on foot & 0.381 & $6.796 \S$ & $\wedge$ & $\wedge$ & 0.390 & $6.192 \S$ & 0.350 & $5.286 \S$ \\
\hline $\mathrm{He} /$ she is currently a transhumant by truck & $\wedge$ & $\wedge$ & $\wedge$ & $\wedge$ & $\wedge$ & $\wedge$ & $\wedge$ & $\wedge$ \\
\hline $\mathrm{He} / \mathrm{she}$ has done transhumance on foot at least once & $\wedge$ & $\wedge$ & $\wedge$ & $\wedge$ & $\wedge$ & $\wedge$ & $\wedge$ & $\wedge$ \\
\hline $\mathrm{He} / \mathrm{she}$ has done transhumance by train at least once & 0.133 & $1.669 \S$ & $\wedge$ & $\wedge$ & 0.146 & 1.621 & 0.126 & 1.337 \\
\hline$R^{2}$ & 0.615 & & 0.41 & & 0.500 & & & 462 \\
\hline$R^{2}$ adjusted & 0.593 & & 0.38 & & 0.476 & & & 431 \\
\hline $\mathrm{AIC}$ & -533.75 & & -393. & 054 & -388.5881 & & -386 & 5.776 \\
\hline $\begin{array}{l}\dagger \text { significant at the } \leq 10 \% \\
\$ \text { significant at the } \leq 5 \% \text { level } \\
\S \text { significant at the } \leq 1 \% \text { level } \\
\wedge \text { variable not selected by the best model }\end{array}$ & & & & & & & & \\
\hline
\end{tabular}

In sum, the most important factors associated with TEK scores in the four models were age, gender, continuing to practice transhumance on foot or having done it in recent years, and full-time livestock raising. Education level was negatively associated with all TEK indexes, but this relationship was not significant in any model.

\section{Traditional ecological knowledge elements as examples of adaptive strategies}

From the whole inventory of identified transhumance-related TEK on the CDR, we identified 14 examples of knowledge, practices, or beliefs that are described in Table 5, and which we used to illustrate adaptive strategies according to previously categorized typologies (Agrawal 2008, GómezBaggethun et al. 2012). Three strategies were included in the mobility category, four strategies were included in the diversification category, and three practices were selected to illustrate the three remaining categories of selection, communal pooling, and forecasting.

\section{DISCUSSION}

\section{Transhumance-related traditional ecological knowledge and its holders}

We identified two main categories of elements related to transhumance-related TEK: (1) TEK that had been abandoned due to obsolescence or replacement with new forms of knowledge, and (2) TEK that remained in use because it could not be replaced by any other technical knowledge because the replacement was less effective or more expensive than the traditional practice, or because the practice was strongly linked to cultural identity. However, TEK that has seemingly become obsolete under present socioeconomic and technological conditions may illuminate the path to future scenarios. For example, rising oil prices in relation to the peak oil and the decline in energy returns on investment provide an economic incentive to resume transhumance on foot. Knowing when/ how/where to walk the drove road instead of using a truck might become even more useful in this context. Second, with rising prices of imported livestock feed, transhumance to take advantage of pasture productivity becomes a more appealing option. Third, the use of dog breeds such as mastiffs, which were previously raised and trained to protect herds from wolf attacks, may become relevant again if large predators reappear. Other TEK remains in use mainly because of the lack of effective substitutes. For example, shepherds apply blood from a cut on the ear to the eyes of sheep to heal keratoconjunctivitis (or "the clouds in an eye"); they also recognize their animals by the sound of their bells. These practices could be considered living evidence of TEK that has survived for centuries and remains in use.

The diversity of informants who hold TEK showed rich causal relationships to the practice of transhumance. TEK holders included a few young people who were involved in transhumance; young informants who had emigrated to urban 
Table 5. Adaptation strategy categories (based on Agrawal 2008, Gómez-Baggethun et al. 2012), with examples derived from transhumance on the Conquense Drove Road (TEK: traditional ecological knowledge).

\begin{tabular}{|c|c|c|}
\hline Categories & Adaptive strategy & Examples of transhumance-related TEK \\
\hline \multirow[t]{3}{*}{ Mobility } & $\begin{array}{l}\text { Temporal use of } \\
\text { pasturelands }\end{array}$ & $\begin{array}{l}\text { - Dehesa use by livestock only in winter, allowing for tree regeneration (Carmona et al. 2013) } \\
\text { - Highland pastures use only in summer } \\
\text { - Redileo, i.e., to pen livestock at night in folds that are moved every three to five days in order to improve } \\
\text { pastures and comply with the carrying capacity of the ecosystem }\end{array}$ \\
\hline & $\begin{array}{l}\text { Flexibility in the } \\
\text { selection of the } \\
\text { wintering areas }\end{array}$ & $\begin{array}{l}\text { - Before the incorporation of women and the rest of the family to transhumance and hence the creation of } \\
\text { social links to a certain town, shepherds chose the wintering rangelands every year depending on pasture } \\
\text { availability and quality, and on rangelands prices }\end{array}$ \\
\hline & $\begin{array}{l}\text { Availability of an } \\
\text { extended and well- } \\
\text { connected network of } \\
\text { drove roads }\end{array}$ & $\begin{array}{l}\text { - Knowledge about the drove roads network protected by the State with the priority use for livestock, } \\
\text { allowing mobility within a matrix of agricultural landscapes, urban settlements, highways, and railroads } \\
\text { - Logistics during transhumance trip, conflict resolution with farmers, and dealing with weather } \\
\text { uncertainties }\end{array}$ \\
\hline \multirow[t]{4}{*}{ Diversification } & $\begin{array}{l}\text { Institutional diversity } \\
\text { at different scales }\end{array}$ & $\begin{array}{l}\text { - Combination between formal institutions such as nongovernmental organizations or local administrations, } \\
\text { and informal institutions such as land tenure regimes, social networks of mutual support for resources } \\
\text { management at different scales, from European to municipal }\end{array}$ \\
\hline & $\begin{array}{l}\text { Diversity of income } \\
\text { sources }\end{array}$ & $\begin{array}{l}\text { - Diversified production of meat and wool, and employment (e.g., in other agrarian activities, such as olive } \\
\text { picking in winter, shearing in spring, or mushroom gathering by the end of the summer or early fall) among } \\
\text { household members to cope with market uncertainties }\end{array}$ \\
\hline & $\begin{array}{l}\text { Diverse sanitary } \\
\text { practices }\end{array}$ & $\begin{array}{l}\text { - Combination of new medicines, such as vaccines, and natural remedies } \\
\text { - Maintenance of no technology-dependent practices and knowledge, such as the adoption of orphan lambs, } \\
\text { herds, and pasturelands management }\end{array}$ \\
\hline & $\begin{array}{l}\text { Diversity of social } \\
\text { contexts }\end{array}$ & - Know-how of transhumant families in different ecosystems and social contexts \\
\hline Selection & Well-adapted breeds & - Transhumant breeds, such as the Merino sheep, adapted to long walks and climate extremes \\
\hline Communal pooling & $\begin{array}{l}\text { Common pasturelands } \\
\text { (summering area) }\end{array}$ & $\begin{array}{l}\text { - Local shepherds have the right to access common pasturelands at very low prices, what constitutes an } \\
\text { "insurance" against increasing prices of private rangelands }\end{array}$ \\
\hline Forecasting & $\begin{array}{l}\text { Interpretation of } \\
\text { animal behavior }\end{array}$ & $\begin{array}{l}\text { - According to the herds' behavior (e.g., nervousness, anxiously feeding, excessive quiet), livestock raisers } \\
\text { usually know when the weather is going to change } \\
\text { - Seeing some wild species wandering around, such as toads moving upwards, indicating rain coming soon, } \\
\text { and if walking downwards, indicating the absence of rain in the following days }\end{array}$ \\
\hline
\end{tabular}

areas but continued to participate in migrations and thus remained in contact with TEK; middle-aged shepherds who drove livestock by truck but considered a return to drove road use as an alternative in times of crisis; a few people who continued the practice of transhumance on foot; and many elders who were retired or were settled and continued to raise livestock. Our classification revealed that social groups are defined by a complex combination of factors, which reflects the intricacy of the current socioeconomic context underlying transhumance. The quantitative approach of the present study may have obscured the qualitative effects of identity, tradition, and other cultural values in keeping TEK: social groups might show a gradient such that people with more deeply rooted transhumance identity might have higher levels of TEK, irrespective of other sociodemographic characteristics.

\section{Factors influencing traditional ecological knowledge maintenance}

This study identified the following main factors that influence the maintenance of transhumance-related TEK: generational change, continuing to walk the drove road, full-time dedication to livestock raising, and gender. In this section, we also discuss the role of education with reference to the results of similar studies in Spain.

\section{Generational change}

TEK scores were lower in the youngest generation than in all other generations. Gómez-Baggethun et al. (2012) found similar patterns of TEK loss in agricultural systems in Doñana, Spain, where traditional knowledge and beliefs tended to erode with market integration and mechanization. In the present study, the Use index was also lower among retired shepherds and young informants who were no longer involved in 
livestock raising. These results suggest that TEK is a function of use rather than age. Active shepherds, especially those in the mature generation, continued to use traditional practices. TEK scores were homogeneous among informants aged 3668 years, but middle-aged informants used TEK less than those in the mature generation, which indicates a breakpoint in the transmission of transhumant-related knowledge. Studies of TEK loss usually pay limited attention to whether people use that knowledge (Gómez-Baggethun and Reyes-García 2013), which may limit the ability to investigate the chances for effective transmission.

TEK is preserved mainly through use, and TEK that is not used is more easily lost; thus, the relative difference between TEK and its use in each group/generation can be interpreted as a proxy of the amount of remaining TEK likely to be lost (Reyes-García et al. 2007). The elderly generation in this study maintained high levels of TEK, but they no longer used it because they were retired or because the specific knowledge they held was no longer useful in present ecological and socioeconomic conditions; this knowledge is thus renewed less often and is more likely to become obsolete. Older active shepherds still used TEK, which suggests that this knowledge remained relevant even in the context of present technologies and regulations. However, middle-aged shepherds who preserved TEK used it less often than did older active shepherds, possibly because their younger age led them to more easily incorporate innovations. Finally, the youngest generation, which became active only after the intensification that accompanied the Green Revolution, held less TEK and put it into practice to a very limited extent. This generation had not experienced traditional transhumance with few inputs of energy and machinery, separation from families, and extremely harsh conditions for shepherds. These intergenerational differences seem to be related more to recent historical changes than to the learning process taking place as people age. For example, formal regulations that prohibit some traditional sanitary practices based on minimal-impact surgery or medicinal plants could have been drivers of TEK loss. The level of TEK was higher in the oldest generation than in the youngest generation, while no loss was observed among interviewees aged 36-68 years, which suggests that TEK loss is not necessarily associated with a failure in the mechanisms of cultural transmission of knowledge but rather with contextual factors affecting the applicability of TEK.

What are the drivers behind the loss of transhumance-related TEK? In agreement with previous research on TEK in Spain (Ruiz and Ruiz 1989, Barrios et al. 1992, Gómez-Baggethun et al. 2010, Gómez-Baggethun and Reyes-García 2013), our results suggest that declining levels of TEK are related to the abandonment of transhumance on foot due to economic development and market integration, technological change, and enforcement of sanitary regulations. Our research also suggests that TEK loss is related to cultural changes in lifestyles. In the last five decades, Spanish agriculture and pastoralism have undergone major changes (Naredo 2004). By the 1960s, Spain had entered a period of rapid economic development that led to a massive rural exodus and the intensification of agriculture (Pineda 2001), which reduced the number of potential TEK carriers. The integration of Spain in the EU and the introduction of the Common Agricultural Policy accelerated this process by providing incentives for intensification (Caraveli 2000, Manzano-Baena and Casas 2010). The rural exodus and the consequent and progressive abandonment of traditional resource management practices with technification and sedentarization fostered the replacement of TEK with new forms of knowledge and practices (Berkes et al. 2000, Pilgrim et al. 2008, EME 2011, Gómez-Baggethun et al. 2012). In Spain, the loss of traditional practices accelerated in the 1980s, coinciding with low oil prices and the development of new transportation infrastructure (Oteros-Rozas et al. 2012b). Arguably, these factors are fundamental drivers underlying the failure to transmit TEK to younger generations.

This situation, however, may be reaching a tipping point. The severe economic crisis in Spain and throughout Europe, and increased production costs associated with rising commodity prices, favor a return to low-input transhumant practices, albeit hybridized with modern means (Fernández-Giménez and Fillat Estaque 2012). Given the presence of substantial pockets of TEK in the study area, partial recovery of transhumant practices has been possible in recent years and is likely to continue in the future.

\section{Walking the drove road}

The most significant factor influencing TEK maintenance was whether informants continued to walk the drove road. Experience with at least one transhumant trip by train, which entailed walking the drove road for 2-5 days to reach the train station, was also related to higher TEK scores. The smallest difference between TEK and Use indexes was among middleaged and young informants with no familial tradition of transhumance but who had experience with trips in which they helped family members or friends. Transhumants who traveled by truck and those who had settled but continued to raise livestock had lower TEK scores than experienced transhumants but the same average Use index. These results can be explained by transhumants' engagement in practices devoted to collectively recalling past experiences during trips, such as storytelling, interpretation of animal behavior, health care practices, searching for high-quality pastures and water, and dealing with disturbances, such as unexpected fires or conflicts with local farmers. These practices and rituals serve to maintain TEK and facilitate its transmission.

Full-time dedication to livestock raising

Active livestock raising was also a key element in the maintenance of TEK. Among informants in groups A and B, 
who had the weakest relationships to transhumance, the associations between Use and TEK indexes were very similar, but active shepherds tended to have and use more TEK than did others. Full-time shepherds, as opposed to those who merely accompany their fathers/brothers during trips, may gain TEK by asking transhumants questions because they share a profession. Some are even employed occasionally by transhumants to help with the herd during trips.

\section{Gender}

Men tended to have higher levels of TEK than did women. However, this finding must be interpreted cautiously given the strong gender bias in our sample selection. Very few women are fully involved in transhumance, and even fewer are officially registered as farmers; most daughters of transhumants emigrate or gain employment in other activities, and we encountered no woman involved in transhumance who had not inherited the tradition from her family or who was not married to a transhumant shepherd. This situation compromises generational renewal because the difficulty of finding a partner who is willing to adapt to the transhumant lifestyle constitutes a social constraint for young individuals and is a clear example of agrarian masculinization (FernándezGiménez and Fillat Estaque 2012).

\section{Education}

In contrast to the findings of other studies (e.g., Benz et al. 2000), formal education did not seem to have a significant influence on the level of TEK in the present study. This finding may be related to the standardization of education in rural Spain, which has eliminated conspicuous differences in educational level in the population. This situation contrasts with those in many other countries, where lower educational levels are found in rural areas. The children of transhumants previously remained with their mothers in the summering area during the school year. Since the 1980s, however, most transhumant families travel together; children typically begin the school year in the summering area and then move to the wintering area to complete the academic year. Transhumanceassociated TEK is not included in formal education at any level in Spain, which eliminates any potential interference due to the acquisition of different types of knowledge in school. The effects of cultural identity, experiential learning through transhumance practice, raising livestock, or belonging to a certain generation seemed to be stronger explanatory variables than education in TEK maintenance. Other studies in Spain have found similar results (Gómez-Baggethun et al. 2010, Iniesta-Arandia et al., personal communication). However, more research is needed to further explore the relationships between TEK maintenance and education in northern European countries, where traditional practices are still preserved in contexts of largely extended formal education.

\section{Transhumance-related traditional ecological knowledge and adaptation to global change}

Previous studies have demonstrated the relevance of traditional knowledge for resource management in different ecosystems (Berkes 1999). The role of TEK in building resilience to disturbance can be especially critical for communities that rely on ecosystem services as primary sources of provisions or income (Gómez-Baggethun et al. 2010). TEK might also serve as a reservoir of information, practices, and institutions to be drawn upon when a community confronts novel changes (Berkes et al. 2003). Examples of transhumance-related TEK identified in the CDR case study (Table 5) illustrate adaptive strategies of mobility, diversification, selection, communal pooling, and forecasting (Agrawal 2008, Gómez-Baggethun et al. 2012), which can contribute to the resilience of the social-ecological system.

Mobility is widely recognized as an important adaptive strategy used by pastoralists (Fernández-Giménez and Le Febre 2006). Some examples of mobility strategies adopted on the CDR are the redileo, a common practice in the dehesas of the wintering area, and flexibility in the annual selection of rangelands according to pasture availability and prices. Another adaptive strategy consists of diversification because it facilitates the pooling of risks across the assets and resources of households and collectives (Agrawal 2008). In this case, the diversification of institutions is exemplified in local committees that arrange the use of common pasturelands, the temporal alignment of shepherds' schedules to share the trip, and the ancient transhumant association called "Mesta" (García-Martín 2004). Shepherds also diversified income sources from the herd, such as meat, leather, and wool. The selection of autochthonous breeds, especially those well adapted to walking long distances and to climatic extremes, is crucial for transhumance. Locally adapted livestock varieties have been largely valued as fundamental in the adaptation to global environmental change (Altieri and Koohafkan 2008, Gómez-Baggethun et al. 2012). Common resources and related institutions have been priced largely on the basis of their reliability in the face of uncertainty and perturbations (Ostrom 1990). In this case, communal pooling constitutes a guarantee of access to resources, which is especially important under conditions of large fluctuations in rangeland rental prices, which occur in wintering areas because of competition with other land uses such as recreational hunting and biodiversity conservation. Most pasturelands in the summering area are communal, and local shepherds have the right to pooled use. Forecasting has also been recognized as an adaptive strategy to changing environments (Morton 2007). An example of this strategy involves knowledge about animal behaviors that act as weather indicators, such as general nervousness, nervous feeding, and excessive stillness, depending on the area, season, breed, and 
herd. Moreover, we noticed that changes in the dates of movements were reported as consequences of adaptation to climate, such as increasing temperatures earlier in spring, and market fluctuations, such as reduced profitability forcing the practice of more than one farrowing per year.

Adaptation to global change requires response to opportunities for environmental and socioeconomic sustainability and the revisiting of past strategies that embody social and ecological memory (see Barthel 2013) to build resilience to deal with crises (Gómez-Baggethun et al. 2012). The maintenance of mobile pastoralism and preservation of knowledge necessary to conduct those activities in a sustainable way thus seems important, not as a bucolic reminder of idyllic past times that never existed but as a useful strategy to deal with growing challenges posed by accelerated global change. As TEK increases the capacity of social-ecological systems to deal with disturbances and maintain resource flows in changing and uncertain conditions (Berkes et al. 2000, Folke et al. 2003), we believe that transhumance-related TEK can help to build resilience, thereby enabling communities to cope with disturbances such as climate change and fluctuating market prices. Our research findings suggest that the potential for the recovery of transhumance remains. Fernández-Giménez and Fillat Estaque (2012) recently reported on the revival of transhumance in the Valley of Hecho in northern Spain. Moreover, the economic crisis in Spain seems to have triggered the return of young people to the countryside and to agrarian practices.

Our understanding of how global change may affect the livelihoods of pastoralists still suffers from substantial gaps. Mobility has always been and will continue to be an important adaptational strategy in the face of global change (Berkes and Jolly 2001, Agrawal 2008, Gómez-Baggethun et al. 2012). Understanding the factors that have made transhumance adaptive in the face of past crises can provide important insight about how to face global change under present conditions. The management of risks in food production caused by fluctuations in primary productivity and water availability is a major challenge for human populations (Ericksen 2008). In developed countries, small-scale farmers and pastoralists can either completely disappear or play a key role in building social-ecological resilience. Emerging movements calling for agroecology and food sovereignty together with an increased demand for organic food appear to be potential niches for traditional production systems like transhumance. Nevertheless, the primary sector's loss of socioeconomic prominence in developed countries leaves little space in the short term for economic activities that sustain living TEK systems, which threatens the survival of important pockets of knowledge that are useful for the future, such as those presented here.

\section{CONCLUSION}

We found that a rich body of TEK persists among Spanish transhumant shepherds. However, a marked loss of TEK was observed among transhumants born after 1975, who held about one-fifth less TEK than did transhumants from other generations. Transhumance-related TEK is being replaced or its practice hindered as sophisticated technologies render it obsolete or provide means of saving time and effort. Our results show that transhumance-related TEK will remain only if the activity survives. When access to technological means becomes more expensive but different mobility strategies are available, the return to traditional practices emerges as an adaptive strategy and reinforces TEK, thereby triggering a positive feedback loop. Further research should be developed in order to provide insights on how the generational turnover of the transmission and use of TEK could be reinforced. In particular, we suggest the analysis of (a) formal and informal institutions that are sustaining or hindering the practice, and (b) gender forces that are influencing young peoples' decisions about whether to be transhumant or not. The study of mobility systems such as transhumance can improve our understanding of how to increase the resilience of social-ecological systems in the current context of great socioeconomic and ecological uncertainty.

Responses to this article can be read online at: http://www.ecologyandsociety.org/issues/responses. $\mathrm{php} / 5597$

\section{Acknowledgments:}

This research was financed by the Spanish Ministry for the Environment and Rural and Marine Affairs (Project 079/ RN08/02.1) and the Ministry of Economy and Competitiveness (Project CGL2011-30266). We are grateful to the Museo de la Trashumancia (Guadalaviar) and especially to all informants for their willingness to share their knowledge. We thank Violeta Hevia, Pedro Zorrilla, César A. López, and Berta MartínLópez for field assistance, assistance with cartography, suggestions regarding data analysis, and comments on early versions of this article; Esteve Corbera and three anonymous reviewers for insights and comments on the manuscript; and participants from the session 16 of the 13th Conference of the International Society of Ethnobiology (Montpellier).

\section{LITERATURE CITED}

Abellán, A., and A. Olivera. 1979. La trashumancia por ferrocarril en España. Estudios Geográficos 40:156-157. 
Agrawal, A. 2008. The role of local institutions in adaptation to climate change. Paper presented at the Social Dimensions of Climate Change Workshop. World Bank, Washington, D. C., USA.

Alerstam, T., A. Hedenstrom, and S. Akesson. 2003. Longdistance migration: evolution and determinants. Oikos 103:247-260. http://dx.doi.org/10.1034/j.1600-0706.2003.12559. $\underline{\mathrm{x}}$

Altieri, M., and P. Koohafkan. 2008. Enduring farms: climate change, smallholders and traditional farming communities. Third World Network, Malaysia.

Bacaicoa Salaverri, I., J. M. Elías Pastor, and J. Grande Ibarra. 1993. Cuadernos de la trashumancia 8. Albarracín - Cuenca - Molina. ICONA, Madrid, Spain. [online] URL: http://www. magrama.gob.es/es/biodiversidad/temas/ecosistemas-y-conectividad/ vias-pecuarias/num 1 al12 vias pecuarias.aspx\#para7

Barrios, J. C., M. T. Fuentes, and J. P. Ruiz. 1992. El saber ecológico de los ganaderos de la sierra de Madrid. Comunidad de Madrid, Madrid, Spain.

Barthel, S., C. L. Crumley and U. Svedin 2013. Biocultural refugia: combating the erosion of diversity in landscapes of food production. Ecology and Society 18 in press. Benz, B. F., J. Cevallos, F. Santana, J. Rosales, and S. Graf. 2000. Losing knowledge about plant use in the Sierra de Manantlan Biosphere Reserve, Mexico. Economic Botany 54:183-191. http://dx.doi.org/10.1007/BF02907821

Berkes, F. 1999. Sacred ecology: traditional ecological knowledge and resource management. Taylor and Francis, Philadelphia, USA and London, UK.

Berkes, F., J. Colding, and C. Folke. 2000. Rediscovery of traditional ecological knowledge as adaptive management. Ecological Applications 10:1251-1262. http://dx.doi. org/10.1890/1051-0761(2000)010[1251:ROTEKA]2.0.CO;2

Berkes, F., J. Colding, and C. Folke. 2003. Navigating socialecological systems: building resilience for complexity and change. Cambridge University Press, Cambridge, UK. http:// dx.doi.org/10.1017/CBO9780511541957

Berkes, F., and D. Jolly. 2001. Adapting to climate change: social-ecological resilience in a Canadian western Arctic community. Conservation Ecology 5(2): 18.

Bernard, H. R. 2005. Research methods in anthropology. Qualitative and quantitative approaches. Altamira Press, Walnut Creek, California, USA.

Bilbao, L. M., and E. Fernandez de Pinedo. 1982. Exportation des laines, transhumance et occupation de l'espace en Castille aux XVI, XVII et XVIIIrme siecles. 8th International Economic History Congress, Budapest, Hungary.
Blondel, J. 2006. The 'design' of Mediterranean landscapes: a millennial story of humans and ecological systems during the historic period. Human Ecology 34:713-729. http://dx.doi. org/10.1007/s10745-006-9030-4

Bunce, R., I. D. Aranzabal, M. Schmitz, and F. Pineda. 2006. A review of the role of Drove Roads (Cañadas) as ecological corridors. Alterra-rapport 1428. Wageningen, The Netherlands. [online] URL: http://content.alterra.wur.nl/Webdocs/PDFFiles/ Alterrarapporten/AlterraRapport1428.pdf

Caraveli, H. 2000. A comparative analysis on intensification and extensification in Mediterranean agriculture: dilemmas for LFAs policy. Journal of Rural Studies 16:231-242. http:// dx.doi.org/10.1016/S0743-0167(99)00050-9

Carmona, C. P., F. M. Azcárate, E. Oteros-Rozas, J. A. González, and B. Peco. 2013. Assessing the effects of seasonal grazing on holm oak regeneration: implications for the conservation of Mediterranean dehesas. Biological Conservation 159:240-247. http://dx.doi.org/10.1016/j. biocon.2012.11.015

Cazorla, A., I. De los Ríos, J. Merino, and J. L. Alier. 2008. A multicriteria assessment model for evaluating droving route networks. Biosystems Engineering 100:601-611. http://dx. doi.org/10.1016/j.biosystemseng.2008.05.001

Davies, J., and R. Hatfield. 2007. The economics of mobile pastoralism: a global summary. Nomadic Peoples 11:91-116. http://dx.doi.org/10.3167/np.2007.110106

Dong, S., L. Wen, S. Liu, and X. Zhang. 2011. Vulnerability of worldwide pastoralism to global changes and interdisciplinary strategies for sustainable pastoralism. Ecology and Society 16(2):10. [online] URL: http://www. ecologyandsociety.org/vol16/iss2/art10/ES-2011-4093.pdf

Dyson-Hudson, R., and N. Dyson-Hudson. 1980. Nomadic pastoralism. Annual Review of Anthropology 9:15-61. http:// dx.doi.org/10.1146/annurev.an.09.100180.000311

Ericksen, P. J. 2008. What is the vulnerability of a food system to global environmental change? Ecology and Society 13 (2):14. [online] URL: http://www.ecologyandsociety.org/ vol13/iss2/art14/

Evaluación de los Ecosistemas del Milenio de España (EME). 2011. La Evaluación de los Ecosistemas del Milenio de España. Síntesis de resultados. Fundación Biodiversidad. Ministerio de Medio Ambiente, y Medio Rural y Marino, Madrid, Spain. [online] URL: http://www.fundacionbiodiversidad.es/images/stories/recursos/proyectos/biodiversidad/2008/ fgua/lecomilenio.pdf

Fernández-Giménez, M. E., and F. Fillat Estaque. 2012. Pyrenean pastoralists' ecological knowledge: documentation and application to natural resource management and 
adaptation. Human Ecology 40(2):287-300. http://dx.doi.org/ http://dx.doi.org/10.1007/s10745-012-9463-x

Fernández-Giménez, M. E., and S. Le Febre. 2006. Mobility in pastoral systems: dynamic flux or downward trend? International Journal of Sustainable Development \& World Ecology 13:22. http://dx.doi.org/http://dx.doi. org/10.1080/13504500609469685

Folke, C., J. Colding, and F. Berkes. 2003. Synthesis: building resilience and adaptive capacity in social-ecological systems. Pages 352-387 in F. Berkes, J. Colding, and C. Folke, editors. Navigating social-ecological systems: building resilience for complexity and change. Cambridge University Press, Cambridge, UK. http://dx.doi.org/10.1017/CBO9780511541957.020

Galvin, K. A. 2009. Transitions: pastoralists living with change. Annual Review of Anthropology 38:185-198. http:// dx.doi.org/10.1146/annurev-anthro-091908-164442

García-Llorente, M., B. Martín-López, and C. Montes. 2011. Exploring the motivations of protesters in contingent valuation: insights for conservation policies. Environmental Science and Policy 14:76-88. http://dx.doi.org/10.1016/j. envsci.2010.11.004

García-Martín, P. 2004. The history and characteristics of the Mesteña Transhumance Routes. Pages 255-258 in R. G. H. Bunce, M. Pérez-Soba, R. H. G. Jongman, A. Gómez Sal, F. Herzog, and I. Austad, editors. Transhumance and biodiversity in European mountains. Report from the EU-FP5 project Transhumount. IALE Publication Series No. 1, Alterra, Wageningen, The Netherlands.

García-Martínez, A., A. Olaizola, and A. Bernués. 2009. Trajectories of evolution and drivers of change in European mountain cattle farming systems. Animal 3:152-165. http:// dx.doi.org/10.1017/S1751731108003297

Garzón, J. 2001. Importancia de la trashumancia para la conservación de los ecosistemas en España. [online] URL: http://dialnet.unirioja.es/servlet/articulo?codigo $=3065605$

Gómez-Baggethun, E. G., S. Mingorría, V. Reyes-García, L. Calvet, and C. Montes. 2010. Traditional ecological knowledge trends in the transition to a market economy: empirical study in the Doñana natural areas. Conservation Biology 24:721-729. http://dx.doi.org/10.1111/ j.1523-1739.2009.01401.x

Gómez-Baggethun, E., and V. Reyes-García. 2013. Reinterpreting change in traditional ecological knowledge. Human Ecology 41(4):643-647.

Gómez-Baggethun, E., V. Reyes-García, P. Olsson, and C. Montes. 2012. Traditional ecological knowledge and community resilience to environmental extremes: a case study in Doñana, SW Spain. Global Environmental Change 22
(3):640-650. http://dx.doi.org/http://dx.doi.org/10.1016/j. gloenvcha.2012.02.005

Gómez Sal, A. 2000. The variability of Mediterranean climate as an ecological condition of livestock production systems. Pages 3-12 in F. Guessous, N. Rihani, and A. Iham, editors. Livestock production and climatic uncertainty in the Mediterranean. EAAP Publication No. 186:94, Wageningen, The Netherlands.

Gómez Sal, A., and I. Lorente. 2004. The present status and ecological consequences of transhumance in Spain. Pages 233-248 in R. G. H. Bunce, M. Pérez-Soba, R. H. G. Jongman, A. Gómez Sal, F. Herzog, and I. Austad, editors. Transhumance and biodiversity in European mountains. Report from the EU-FP5 project Transhumount. IALE Publication Series No. 1, Alterra, Wageningen, The Netherlands.

González J. A., E. Oteros-Rozas, B. Martín-López, C. A. López, P. Zorrilla, and C. Montes. 2012. La trashumancia en la Cañada Real Conquense: valores ecológicos, sociales y económicos asociados a una práctica ganadera tradicional. Universidad Autónoma de Madrid, Madrid. [online] URL: http://www.uam.es/gruposinv/socioeco/documentos/INFORME\% 20TRASHUMANCIA_SINTESIS\%20TOMADORES\% 20DECISIONES.pdf

Hatfield, R., and J. Davies. 2006. Global review of the economics of pastoralism. Prepared for the World Initiative for Sustainable Pastoralism. IUCN, Nairobi, Kenya.

Huntington, H. P. 2000. Using traditional ecological knowledge in science: methods and applications. Ecological Applications 10:1270-1274. http://dx.doi.org/10.1890/1051-0761 (2000)010[1270:UTEKIS]2.0.CO;2

Iniesta-Arandia, I., D. García del Amo, A. P. García-Nieto, C. Piñeiro, C. Montes, and B. Martín-López. Under review. Factors influencing local ecological knowledge maintenance in Mediterranean watersheds: insights for conservation policies.

Janssen, M., O. Bodin, J. M. Anderies, T. Elmqvist, H. Ernstson, R. R. J. McAllister, P. Olsson, and P. Ryan. 2006. Toward a network perspective of the study of resilience in socio-ecological systems. Ecology and Society 11(1):15 [online] URL: http://www.ecologyandsociety.org/vol11/iss1/ $\underline{\operatorname{art} 15 /}$

Knapp, C. N., and M. E. Fernández-Giménez. 2009. Knowledge in practice: documenting rancher local knowledge in northwest Colorado. Rangeland Ecology \& Management 62:500-509. http://dx.doi.org/10.2111/08-175.1

Mangas-Navas, J. M. 2004. Recovery of the national network of transhumance routes: program of the Ministry of the Environment. Pages 265-270 in R. G. H. Bunce, M. Pérez- 
Soba, R. H. G. Jongman, A. Gómez Sal, F. Herzog, and I. Austad, editors. Transhumance and biodiversity in European mountains. Report from the EU-FP5 project Transhumount. IALE Publication Series No. 1, Alterra, Wageningen, The Netherlands.

Manzano, P., and J. E. Malo. 2006. Extreme long-distance seed dispersal via sheep. Frontiers in Ecology and the Environment 4:244-248. http://dx.doi.org/10.1890/1540-9295 (2006)004[0244:ELSDVS]2.0.CO;2

Manzano-Baena, P., and R. Casas. 2010. Past, present and future of Trashumancia in Spain: nomadism in a developed country. Pastoralism 1:72-90.

Morton, J. F. 2007. The impact of climate change on smallholder and subsistence agriculture. Proceedings of the National Academy of Sciences of the United States of America 104:19680-19685. http://dx.doi.org/10.1073/pnas.0701855104

Naredo, J. M. 2004. La evolución de la agricultura en España (1940-2000). Universidad de Granada, Granada, Spain.

Nori, M., and J. Davies. 2007. Change of wind or wind of change? Climate change, adaptation and pastoralism. The World Initiative for Sustainable Pastoralism. IUCN, Nairobi, Kenya.

Ostrom, E. 1990. Governing the commons: the evolution of institutions for collective action. Cambridge University Press, New York, USA. http://dx.doi.org/10.1017/CBO9780511807763

Oteros-Rozas, E., J. A. González, B. Martín-López, C. A. López, and C. Montes. 2012b. Ecosystem services and socialecological resilience in transhumance cultural landscapes: learning from the past, looking for a future. Pages 242-260 in $\mathrm{T}$. Plieninger and C. Bieling, editors. Resilience and the cultural landscape. Understanding and managing change in human-shaped environments. Cambridge University Press, Cambridge, UK. http://dx.doi.org/http://dx.doi.org/10.1017/ CBO9781139107778.018

Oteros-Rozas, E., J. A. González, B. Martín-López, C. A. López, P. Zorrilla-Miras, and C. Montes. 2012a. Evaluating ecosystem services in transhumance cultural landscapes: an interdisciplinary methodological framework. GAIA 21 (3):185-193.

Pilgrim, S. E., L. C. Cullen, D. J. Smith, and J. Pretty. 2008. Ecological knowledge is lost in wealthier communities and countries. Environmental Science \& Technology 42(4):10041009. http://dx.doi.org/10.1021/es070837v

Pineda, F. 2001. Intensification, rural abandonment and nature conservation in Spain. Pages 23-38 in R. G. H. Bunce, M. Pérez-Solba, B. S. Elbersen, M. J. Prados, E. Andersen, M. Bell, and P. J. A. M. Smeets, editors. Examples of European agri-environment schemes and livestock systems and their influence on Spanish cultural landscapes. Alterra Rapport 309, Wageningen, The Netherlands.

Reyes-García, V., V. Vadez, T. Huanca, W. R. Leonard, and T. McDade. 2007. Economic development and local ecological knowledge: a deadlock? Quantitative research from a native Amazonian society. Human Ecology 35(3):371-377. http://dx.doi.org/10.1007/s10745-006-9069-2

Reyes-García, V., V. Vadez, S. Tanner, T. McDade, T. Huanca, and W. R. Leonard. 2006. Evaluating indices of traditional ecological knowledge: a methodological contribution. Journal of Ethnobiology and Ethnomedicine $2: 21$.

Reyes-García, V., S. Vila, L. Aceituno-Mata, L. Calvet-Mir, T. Garnatje, A. Jesh, J. J. Lastra, M. Parada, M. Rigat, J. Valles, and M. Pardo-de-Santayana. 2010. Gendered homegardens: a study in three mountain areas of the Iberian Peninsula. Economic Botany 64:235-247. http://dx.doi.org/10.1007/ s12231-010-9124-1

Ruiz, M., and J. P. Ruiz. 1986. Ecological history of transhumance in Spain. Biological Conservation 37(1):73-86. http://dx.doi.org/10.1017/CBO9781139107778.018

Ruiz, M., and J. P. Ruiz. 1989. Landscape perception and technological change in the central mountains of Spain. Landscape ad Urban Planning 18(1):1-15. http://dx.doi. org/10.1016/0169-2046(89)90052-2

Ward, J. 1963. Hierarchical grouping to optimize an objective function. Journal of the American Statistical Association 58:236-244. http://dx.doi.org/10.1080/01621459.1963.10500845 
Appendix 1. Questions included in the survey, showing how they were combined for the calculation of all traditional ecological knowledge (TEK) and Use indexes (Cronbach's alphas for all the indexes are shown at the end of the table).

Questions included in the survey and their combination for the calculation of TEK indexes

\begin{tabular}{|c|c|c|c|c|c|c|}
\hline $\begin{array}{c}\text { TEK } \\
\text { general }\end{array}$ & $\begin{array}{l}\text { TEK } \\
\text { past }\end{array}$ & $\begin{array}{c}\text { TEK } \\
\text { transhumance }\end{array}$ & $\begin{array}{c}\text { TEK } \\
\text { environment }\end{array}$ & $\begin{array}{c}\text { TEK } \\
\text { indicators }\end{array}$ & $\begin{array}{c}\text { TEK } \\
\text { sanitary }\end{array}$ & Use \\
\hline \multicolumn{7}{|c|}{ (1) } \\
\hline \multicolumn{7}{|l|}{$\mathrm{X}$} \\
\hline $\mathrm{X}$ & & $X$ & & & & \\
\hline $\mathrm{X}$ & $\mathrm{X}$ & $\mathrm{X}$ & & & & \\
\hline X & & & & & & \\
\hline X & & & & & & $\mathrm{X}$ \\
\hline
\end{tabular}

1. In a herd of sheep, is it important to have goats? Why/What for?

2. In a herd of sheep, what is the ideal number of males (in order to maximize productivity)?

3. Which is the maximum size of a herd of sheep so that it can be driven, during

transhumance on foot, by two shepherds with dogs but without horses (plus a person in

charge of logistics, driving the car)?

4. When there used to be just one birth a year per sheep in which time of the year were rams

mixed with sheep (females)? Why?

5 . How many $\mathrm{kg}$ of wool does a merino sheep produce a year, on average? [merino is the

local breed]

6. Do you know any tricks for making a mother adopt a lamb from another sheep when her lamb has died?

7. How do you name sheep out of their teeth?

8. Could you recognize, in this picture, four types of brands in the ears of the sheep? [a panel with 6 drawings was shown]

9. In the past, animals used to be branded with pitch ¿do you know what materials were used to produce pitch? [If yes] ¿How was it made?

10. Apart from the ear and the pitch brand ¿in which other way were sheep branded in order to avoid thefts?

11. Could you name five types of bells and order them from the biggest to the smallest?

12. Nowadays, a bad year with none or little pasture, one can feed the animals but what did

people use to do in the past? [more than 50 years ago]

13. Could you mention two plants from the summering area and two from the wintering area that are good pastures?

14. In the wintering area, when is the saeta good and when is it bad?

15. What does the practice of redileo consist in? What is it good for? [if he/she knows] Why

is the pasture better where this practice is done?

16. In the past, when the herds needed to be pen, what material was used to make the fold

out of? How have this material been changing? [if he/she knows] Why? 
Questions included in the survey and their combination for the calculation of TEK indexes

\begin{tabular}{ccccccc} 
TEK & TEK & TEK & TEK & TEK & TEK & Use \\
general & past & transhumance & environment \\
indicators & sanitary & \\
\hline $\mathrm{X}$ & $\mathrm{X}$ & & & & & \\
$\mathrm{X}$ & & & & $\mathrm{X}$ & & \\
$\mathrm{X}$ & & & $\mathrm{X}$ & $\mathrm{X}$ & & \\
$\mathrm{X}$ & & $\mathrm{X}$ & & & & \\
$\mathrm{X}$ & & $\mathrm{X}$ & $\mathrm{X}$ & $\mathrm{X}$ & & \\
$\mathrm{X}$ & $\mathrm{X}$ & & $\mathrm{X}$ & & $\mathrm{X}$ & $\mathrm{X}$ \\
$\mathrm{X}$ & $\mathrm{X}$ & & $\mathrm{X}$ & & $\mathrm{X}$ & \\
$\mathrm{X}$ & $\mathrm{X}$ & & & $\mathrm{X}$ & $\mathrm{X}$ \\
$\mathrm{X}$ & $\mathrm{X}$ & & & & $\mathrm{X}$ \\
$\mathrm{X}$ & $\mathrm{X}$ & $\mathrm{X}$ & & & \\
$\mathrm{X}$ & & $\mathrm{X}$ & $\mathrm{X}$ & & \\
$\mathrm{X}$ & & $\mathrm{X}$ & $\mathrm{X}$ & & \\
$\mathrm{X}$ & & $\mathrm{X}$ & $\mathrm{X}$ & & \\
$\mathrm{X}$ & & $\mathrm{X}$ & & & \\
$\mathrm{X}$ & $\mathrm{X}$ & & & & \\
$\mathrm{X}$ & $\mathrm{X}$ & $\mathrm{X}$ & & & \\
\end{tabular}

17. How should a mastiff behave during daylight? And in the night? And how should it react if there is a wolf attack to the herd?

18. What do sheep suspect when they eat a lot and look nervous and restless?

19. When big toads are seen around, what do they indicate? Could you name (and explain)

any other animal behavior that indicates environmental changes?

20. Could you complete the proverb: "Rain in January..."

21. Could you describe, season by season, a good meteorological year, for pasturelands and livestock, for transhumants?

22. What causes basquilla among sheep? Do you know any natural remedy or practice to treat it or prevent from it? [basquilla is a disease caused by an entherotoxin produced by

Clostridium perfringens]

23. Do you know any natural remedy or practice to treat mange?

24. Do you know any natural remedy or practice to treat livestock from the deposit of fly

larvae eggs into wounded tissue?

25. Do you know any natural remedy or practice to treat the clouds in the eyes? [clouds in the eyes is the common name for keratoconjunctivitis]

26. When did the trip take longer, before the trains came or now? [if he/she knows] why has this changed?

27. Could you mention at least five municipalities/towns of La-Mancha region that are crossed by the CDR?

28. If you did transhumance on foot next year, what croplands would you need to prevent sheep from feeding on?

29. If you did transhumance on foot next year, what problems might you face during the trip?

30. In which municipalities/towns of La-Mancha region are there more problems with water availability?

31. Which is the traditional date for cutting the tail of the sheep? Why? [Has it changed?]

32. What was used to be done by Saint Michael, on September 29th? Why in that date? 
Questions included in the survey and their combination for the calculation of TEK indexes

$\begin{array}{cc}\text { TEK } & \text { TEK } \\ \text { general } & \text { past }\end{array}$

TEK

TEK

TEK TEK Use

33. What was the zagón and what was it used to be it made out of? And the zaque? [both were recipients made out of sheep and cow leather respectively]

\begin{tabular}{ccccccc} 
general & past & transhumance environment & indicators sanitary & \\
$\mathrm{X}$ & $\mathrm{X}$ & & & & & \\
$\mathrm{X}$ & & & & & \\
$\mathrm{X}$ & & & & & & \\
$\mathrm{X}$ & & & $\mathrm{X}$ & & & \\
& & & & & & \\
0.87 & 0.74 & 0.75 & 0.72 & 0.41 & 0.41 & 0.59 \\
\hline
\end{tabular}

34. Do you know what the somarro is? [is he/she knows] How is it prepared? [somarro a way of preserving sheep meet by drying it]

35. Could you complete the proverb: "The shady size is good..."? What does the above mentioned proverb mean? 